\section{KẾT LUẬN}

Khảo sát 82 đối tượng nghiên cứu bị đau CSTL mạn tính, không phẩn biệt giố tính cho thây: Nồng độ Vitamin D3 huyết thanh trung bình là 19,8 \pm 7,7 ng/ml; trong đó tỷ lệ thiếu nặng chiếm $53,7 \%$ và thiếu vừa là $39,0 \%$. Một số yếu tố ảnh hưởng đến nồng độ Vitamin D3 huyết thanh có ý nghĩa $(p<0,05)$ bao gồm: giới tính, tình trạng hút thuốc lá, tình trạng uống rượu (ở nam giới), triệu chứng yếu cơ trền lâm sàng, mức độ hạn chế sinh hoạt (chỉ số Oswestry), chỉ số ALP, giảm mật độ xương cột sống ở phụ nữ. Những kết quả này cho thấy thực trạng thiếu vitamin D3 đặc biệt ở bệnh nhân đau thắt lưng mãn tính và những khuyến nghị về sự cần thiết phải sàng lọc tình trạng thiếu vitamin $D$ ở những người bệnh bị đau cột sống thắt lưng mạn tính để có kế hoạch điều trị phù hợp.

\section{TÀI LIÊU THAM KHẢO}

1. Đoàn Quốc Hưng (2018). Phương pháp nghiên cứu trong y sinh học (sách đào tạo sau đại học), Nhà Xuất bản Y học, Hà Nội.

2. Lê Anh Thư, Hưỳnh Vằn Khoa, Huỳnh Phan Phúc Linh và cộng sự. (2011). Đánh giá tình trạng vitamin $D$ của bệnh nhân nội trú tại khoa Nội Cở Xương Khớp, Bệnh viện Chợ Rẫy. Tạp chí Y học
TP Hồ Chí Minh, 15(4), 154-159.

3. Bischoff-Ferrari H.A., Dietrich T., Orav E.J., et al. (2004). Higher 25-hydroxyvitamin D concentrations are associated with better lower-extremity function in both active and inactive persons aged $>$ or $=60$ y. Am J Clin Nutr, 80(3), 752-758.

4. Çalık Y., Aygün Ü. (2017). Evaluation of vitamin D levels in patients with chronic low back-leg pain. Acta Orthop Traumatol Turc, 51(3), 243-247.

5. Chou R. (2011). Low Back Pain (Chronic). AFP, 84(4), 437-438.

6. Gokcek E., Kaydu A. (2018). Assessment of Relationship between Vitamin D Deficiency and Pain Severity in Patients with Low Back Pain: A Retrospective, Observational Study. Anesth Essays Res, 12(3), 680-684.

7. Holick M.F., Binkley N.C., Bischoff-Ferrari H.A., et al. (2012). Guidelines for Preventing and Treating Vitamin D Deficiency and Insufficiency Revisited. J Clin Endocrinol Metab, 97(4), 1153-1158.

8. Kanaujia V., Yadav R.K., Verma S., et al. (2021). Correlation between Vitamin D deficiency and nonspecific chronic low back pain: A retrospective observational study. J Family Med Prim Care, 10(2), 893-897.

9. Lodh M., Goswami B., Mahajan R.D., et al. (2015). Assessment of Vitamin D status In Patients of Chronic Low Back Pain of Unknown Etiology. Ind J Clin Biochem, 30(2), 174-179.

\title{
NGHIÊN CỨU BƯớC ĐÂU VỀ CAGPAI, OIPA, DUPA CỦA HELICOBACTER PYLORI Ở BÊ̂NH NHÂN UNG THƯ DẠ DÀY TẠI VIỆT NAM
}

\author{
Vũ Văn Khiên', Đoàn Vũ Nam², Nguyễn Quang Duật ${ }^{2}$, \\ Phạm Hồng Khánh ${ }^{2}$, Trần Thị Huyền Trang ${ }^{1}$
}

\section{TÓM TẮT}

Đặt vấn đê: Từ năm 1994, WHO đã xếp H.pylori nằm trong nhóm I gây UTDD. Tuy nhiên, khả năng gây bệnh của $\mathrm{H}$. pylori phụ thuộc vào yếu tố độc lực của nó. Đề tài nghiên cứu về tỷ lệ cagPAI, oipA, dupA ở bệnh nhân UTDD tại Việt Nam. Đối tướng và phương pháp: 31 bệnh nhẩn UTDD được chẩn đoán xác định trên nội soi và mô bệnh học. CagPAI, oipA, dupA được thực hiện bằng kỹ thuật PCR. Kêt quả: Bệnh nhẩn $\geqq 60$ tuổi chiếm: 64,5\%. Nam nhiều hơn nữ: 2,1 . Các triêu chứng lâm sàng hay gặp: Chán ăn $(90,3 \%)$, khó tiêu $(90,3 \%)$, đau thương vị $(83,9 \%)$. Mô bệnh học: Ung thư dạ dày thể ruột chiếm tỷ lệ cao nhất: $64,5 \%$. Tỷ lệ cagPAI, oipA, dupA dương tính ở bệnh nhân UTDD tương ứng là: $90,3 \%, 32,3 \%$,

\footnotetext{
${ }^{1}$ Bệnh viện TWQĐ 108

Bệnh viện quân y 103-Học viện Quân Y

Chịu trách nhiệm chính: Vũ Vắn Khiên

Email: vuvankhien108@yahoo.com.vn

Ngày nhận bài: 12.5.2021

Ngày phản biên khoa học: 5.7.2021

Ngày duyệt bài: 15.7.2021
}

$51,6 \%$. Kết luân: Gen cagPAI của H. pylori là yếu tố nguy cơ cao gẩy UTDD tại Việt Nam. Cần nghiên cứu trên số lượng nhiều hơn

Tư khóa: Helicobacter pylori, ung thư dạ dày, viêm dạ dày mạn

\section{SUMMARY \\ INITIAL STUDY ON CAGPAI, OIPA, DUPA \\ OF HELICOBACTER PYLORI IN GASTRIC CANCER PATIENTS IN VIETNAM}

Introduction: Since 1994, WHO has classified H.pylori in group I causing gastric cancer. However, the pathogenicity of $\mathrm{H}$. pylori is highly dependent on its virulence factor. Research topic on the rate of cagPAI, oipA, dupA in gastric cancer patients in Vietnam. Patients and mehods: 31 patients with gastric cancer were confirmed on endoscopy and histopathology. CagPAI, oipA, dupA were performed by PCR. Results: Patients $\geqq 60$ years old accounted for: $64.5 \%$. More men than women: 2.1. Common clinical symptoms: Anorexia (90.3\%), dyspepsia $(90.3 \%)$, epigastric pain $(83.9 \%)$. Histopathology: Itestinal type accounted for the highest percentage $(64.5 \%)$. CagPAI, oipA, dupA were positive in gastric 
cancer patients, respectively: $90.3 \%, 32.3 \%, 51.6 \%$. Conclusion: The cagPAI gene of $\mathrm{H}$. pylori is a high risk factor for gastric cancer in Vietnam. Need to study on more quantity

Keywords: Helicobacter pylori, gastric cancer, chronic gastritis

\section{I. ĐĂT VẤN ĐỀ}

Mặc dù có nhiều tiến bộ trong việc phát hiện sớm và áp dụng các kỹ thuật tân tiến điêuu trị cho ung thư dạ dày. Tuy nhiên, ung thư dạ dày (UTDD) vẫn là một trong những loại ung hay gặp trên thế giới. Thống kê của GLOBOCAN 2020 cho biết tỷ lệ mắc UTDD trên toàn thế giới là 1.089 .103 ca và có 768.793 bệnh nhân đã bị tử vong.

Từ năm 1994, tổ chức y tế giới (WHO) đã xếp Helicobacter pylori (H.pylori) nằm trong nhóm I gây UTDD. Tuy nhiên, khả năng gây bệnh của $H$. pylori phụ thuộc rất nhiều vào yếu tố độc lực (virulence factors) của chúng. Yếu tố độc lực cagA (cytotoxin associated gene $A$ ) và vacA (vacuolating cytocin $A$ ) đã được nghiên cứu khá rộng rãi trong UTDD và các bệnh lý dạ dày khác. Tuy nhiên, ngoài 2 gen cagA và vacA còn có khá nhiêu các gen khác cũng được chứng minh có liên quan đến các bệnh lý dạ dày tá tràng, đặc biệt là UTDD. Gần đây, có nhiều nghiên cứu đề cập đến các gen khác như cagPAI (cag pathogenicity island), oipA (outer inflammatory protein $A$ gen) và dupA (duodenal ulcer promoting gen) ở bệnh nhân UTDD [1]. Năm 2010, Nguyến Lâm Tùng và cs cũng đã nghiên cứu các gen này chỉ trên các đối tượng là bệnh nhân bị viêm dạ dày mạn. Đề tài nghiên cứu tìm hiểu về tỷ lệ các gen: cagPAI, oipA, dupA ở bệnh nhân UTDD tại Việt Nam

\section{II. ĐỐI TƯợNG VÀ PHƯƠNG PHÁP NGHIÊN CỨU}

1. Đối tượng. Trong thời gian từ $06 / 2019$ đến 03/2020, chúng tôi đã thu thập được 31 bệnh nhân UTDD đủ tiêu chuẩn được đưa vào nghiên cứu. Bệnh nhân được thu thập tại Bệnh viện TWQĐ 108 và Bệnh viện quân y 103-Học viện Quân y.

Tất cả bệnh nhân UTDD được chẩn đoán xác định bằng mô bệnh học và có nhiếm $H$. pylori (xác định trên urea test và/hoặc PCR). Tiêu chuẩn loại trừ: Đã cắt dạ dày, dùng kháng sinh hoăc Bismuth (trong vòng 4 tuân), dùng thuốc kháng thụ thể $\mathrm{H}_{2}$ hoặc thuốc ức chế bơm proton trong vòng 2 tuần trước đó.

\section{Phương pháp}

+ Thiết kế nghiên cứu: nghiên cứu cắt ngang

+ Sử dụng máy nội soi EVIS 180 (OlympusNhật Bản).

+ Hình ảnh đại thể UTDD dưa theo phân loại của Bormann chia thành 4 thể: Khối lồi, loét, loét thâm nhiễm, thâm nhiễm lan toả.

+ Phân loại mô bệnh học UTDD dựa theo phân loại của Lauren gồm 3 thể: Thể ruột, thể lan tỏa và thể hỗn hợp.

+ Mảnh sinh thiết xét nghiệm $\mathrm{PCR}$ chẩn đoán H. pylori và các yếu tố độc lực cagPAI, oipA và dupA được cố định trong dung dịch transport medium, bảo quản ở nhiệt độ - 80 độ C. Mẫu bệnh phẩm sau đó được bảo quản trong hộp chuyên dụng, vận chuyển đến khoa Sinh học phân tử - Bệnh viện TWQĐ 108 trong cùng ngày.

+ Kít làm sạch QIAquick (Qiagen). Các cặp mồi, enzym dùng trong phản ứng PCR. Máy đọc kết quả điện di: Chemidoc XRS+ BIO-RAD. Hệ thống điện di mao quản với độ phân giải cao: Microchip electrophoresis system for DNA/RNA analysis MCE ${ }^{\circledR}-202$ MultiNA.

+ Gen cagPAI được xác định dựa trên sự có mặt đồng thời của 3 gen: cagA, cagY, cagT.

+ Đối với gen oipA, dupA: Phản ứng PCR được thực hiện bằng cách nâng nhiệt độ của phản ứng lên $94^{\circ} \mathrm{C}$ trong vòng 5 phút, theo sau đó là 35 chu kỳ nhiệt, mỗi chu kỳ bao gồm: Giai đoạn biến tính: $94^{\circ} \mathrm{C}$ trong 30 giây, giai đoạn gắn mồi: $56^{\circ} \mathrm{C}$ trong 30 giây, giai đoạn nối dài: $72^{\circ} \mathrm{C}$ trong 30 giây và cuối cùng là bước kéo dài $72^{\circ} \mathrm{C}$ trong 7 phút.

\section{KẾT QUẢ NGHIÊN CỨU}

Trong thời gian nghiên cứu, chúng tôi mới chỉ thu thập 31 bệnh nhân UTDD đủ tiêu chuẩn đưa vào nghiên cứu. Tất cả các bệnh nhân đều có nhiễm $\mathrm{H}$. pylori và xét nghiệm các gen: cagPAI, oipA và dupA. Sau đây là kết quả cụ thể:

\section{Bảng 3.1. Đặc điểm tuổi, giới, triệu chứng lâm sàng của UTDD}

\begin{tabular}{|c|c|c|c|}
\hline Tuối/giới & $\mathbf{n ~ ( \% )}$ & Lâm sàng & $\mathbf{n ~ ( \% )}$ \\
\hline$<60$ tuối & $11 / 31(35,5)$ & Đau thương vị & $26 / 31(83,9)$ \\
\hline$\geqq 60$ tuối & $20 / 31(64,5)$ & Chán ăn & $28 / 31(90,3)$ \\
\hline Tuối TB & $63,1 \pm 9,2$ & Khó tiêu & $28 / 31(90,3)$ \\
\hline Nam & $21 / 31(67,7)$ & Gầy sút cân & $11 / 31(35,5)$ \\
\hline Nữ & $10 / 31(32,3)$ & Buồn nôn và nôn & $23 / 31(74,2)$ \\
\hline Nam/nữ & $21 / 10(2,1)$ & Đi ngoài phân đen & $3 / 31(9,7)$ \\
\hline
\end{tabular}

Nhận xét: bệnh nhân $\geqq 60$ tuối chiếm: 64,5\%. Nam nhiêu hơn nữ: 2,1. Các triêu chứng lâm sàng 
hay găp: Chán ăn (90,3\%), khó tiêu (90,3\%), đau thượng vị $(83,9 \%)$.

Bảng 3.2. Kêt quả về hình ảnh nội soí của UTDD

\begin{tabular}{|c|c|c|c|}
\hline Phân loại Borrmann & $\mathbf{n ~ ( \% )}$ & Vị trí trên nội soi & $\mathbf{n}(\%)$ \\
\hline Thế lồi & $9 / 31(29,0)$ & Hang vị & $22 / 31(71,0)$ \\
\hline Thế loét & $5 / 31(16,2)$ & Thân vị & $6 / 31(19,4)$ \\
\hline Thể loét xâm nhập & $17 / 31(54,8)$ & Bờ cong nhỏ & $2 / 31(6,5)$ \\
\hline Thế thâm nhiêm lan tỏa & 0 & Bờ cong lớn & $1 / 31(3,1)$ \\
\hline Tống & $\mathbf{3 1 / 3 1}(\mathbf{1 0 0})$ & Tống & \\
\hline
\end{tabular}

Nhận xét: UTDD týp 3 chiếm tỷ lệ cao nhất: 54,8\%. Khối u hang vị chiếm tỷ lệ: 71,0\%.

Bảng 3.3. Kết quả về xét nghiệ̣m gen của UTDD

\begin{tabular}{|c|c|c|c|}
\hline Yếu tố độc lực & $\mathbf{n ~ ( \% )}$ & Tố hợp gen & $\mathbf{n ~ ( \% )}$ \\
\hline cagPAI $(+)$ & $28 / 31(90,3)$ & cagPAI + oipA + dupA $(\mathrm{n}=8)$ & $8 / 31(25,8)$ \\
\hline oipA $(+)$ & $10 / 31(32,3)$ & cagPAI + oipA $(\mathrm{n}=9)$ & $9 / 31(29,0)$ \\
\hline $\operatorname{dupA}(+)$ & $16 / 31(51,6)$ & cagPAI + dupA $(\mathrm{n}=15)$ & $15 / 31(44,4)$ \\
\hline & & oipA + dupA $(\mathrm{n}=9)$ & $9 / 31(29,0)$ \\
\hline & & Không có cả 3 gen $(\mathrm{n}=2)$ & $2 / 31(6,5)$ \\
\hline
\end{tabular}

Nhận xét: Tỷ lệ cagPAI, oipA, dupA dương tính ở bệnh nhân UTDD chiếm tỷ lệ tương ứng: $90,3 \%, 32,3 \%, 51,6 \%$. Tỷ lệ bệnh nhân có 2 gen kết hợp: cagPAI + dupA dương tính chiếm tỷ lệ cao nhất: $15 / 31(44,1 \%)$. Gen oipA $(+)$ và dupA $(+)$ chiếm: $9 / 31(29,0 \%)$

Bảng 3.4. Kêt quả về mô bệnh học UTDD

\begin{tabular}{|c|c|}
\hline Phân loại mố bệnh học & $\mathbf{n}(\%)$ \\
\hline Thế ruột & $20 / 31(64,5)$ \\
\hline Thế lan tỏa & $9 / 31(29,0)$ \\
\hline Thế hồn hợp & $2 / 31(6,5)$ \\
\hline Tống & $\mathbf{3 1 / 3 1}(\mathbf{1 0 0})$ \\
\hline
\end{tabular}

Nhận xét: UTDD thế ruột chiếm tỉ lệ cao nhất $(64,5 \%)$.

\section{BÀN LUẬN}

4.1. Vai trò của gen cagPAI của H.pylori ở bệnh nhân UTDD. Tiểu đảo bệnh sinh cagA (cag pathogenicity island: cagPAI)) gồm nhiêu gen độc lực, đặc biệt là cagA. Sự hiện diện của gen cagA được coi là dấu hiệu cho sự hiện diện của cagPAI. CagA thông qua nhiều cơ chế phức tạp đã được chứng minh có vai trò trong bệnh sinh của UTDD. Gen cagA sẽ kích hoạt SHP-2, gây rối loạn phân bào và tương tác với $\mathrm{E}$ cadherin, gây rối loạn phát triển phôi và cân bằng nội mô và cuối cùng gây UTDD. Gen cagY và cagT mã hóa cho các thành phần của hệ thống bài tiết type IV, có vai trò quan trọng trong vận chuyển cagA vào trong tế bào biểu mô dạ dày. Người nhiếm $\mathrm{H}$. pylori có cagPAI dương tính thường có xu hướng mắc bệnh nặng và dể hình thành UTDD [1]

Bảng 3.4.cho biết tỷ lệ cagPAI dương tính ở bệnh nhân UTDD là: 28/31(90,3\%). Một nghiên cứu tập toàn cầu (global collection) từ 53 vùng địa lý và các chủng tộc khác nhau đã cho biết có sự khác biệt về tỷ lệ cagPAI dương tính ở các vùng địa lý khác nhau. Tỷ lệ cagPAI dương tính chiếm trên $95 \%$ ở Tây Phi, Nam Phi, Trung Á và Đông Á. Tỷ lệ này còn $81 \%$ ở Đông Bắc Phi và chỉ còn $28 \%$ ở Mỹ Latin. Ở châu Âu, tỷ lệ cagPAI (+) ở mức trung bình (58\%). Riêng khu vực châu Á, tỷ lệ cagA chiếm tỷ lệ > 90\%, trong khi đó ở Tuung đông chỉ chiếm khoảng $50 \%$. Do vậy, sự hiện diện của cagPAI của H. pylori sẽ là nguy cơ cao gây UTDD và điều này lý giải về tần suất mắc UTDD tăng lên ở khu vực châu Á so với các khu vực khác.

Nghiên cứu của Ali $M$ và cs [3] phân tích gen cagPAI từ 174 bệnh nhân, bao gồm UTDD, loét da dày, loét tá tràng và chứng khó tiêu chức nằng bằng kĩ thuật $\mathrm{PCR}$. Kết quả cho biết tỷ lệ gen cagPAI ở bệnh nhân UTDD là 85,7\%, trong khi tỉ lệ gen cagPAI ở nhóm bệnh nhân loét tá tràng là $6,9 \%$. Khatoon $\mathrm{J}$ và cs nghiên cứu trên 70 bệnh nhân UTDD, 50 bệnh nhân loét dạ dày, cho biết tỷ lệ gen cagPAI $(+)$ ở bệnh nhân UTDD chiếm: 90\%. Các nghiên cứu kết luận cagPAI của $\mathrm{H}$. pylori là một yếu tố độc lực mạnh ở bệnh nhân UTDD. Nghiển cứu của chúng tôi cho biết tỷ lệ cagPAI (+) ở bệnh nhân UTDD rất cao $(90,3 \%)$. Vì vậy, cagPAI của $\mathrm{H}$. pylori là một yếu tố nguy cơ cao gây UTDD tại Việt Nam. Tuy nhiên, chúng tôi sẽ nghiên cứu trên số lượng nhiều hơn trong thời gian tới.

4.2. Vai trò của gen oipA của H.pylori ở bệnh nhân UTDD. Protein viêm màng ngoài (outer inflammatory protein: oipA) của $\mathrm{H}$. pylori được phát hiện vào năm 2000 bởi Yamaoka Y và CS [1]. OipA là một trong 5 thành viên protein màng ngoài của vi khuẩn $\mathrm{H}$. pylori và do vậy oipA còn có tên gọi tắt khác là hopH. Vị trí của oipA trên nhiễm sắc thể của $\mathrm{H}$. pylori cách cagPAI khoảng 100 kb. Tác động của oipA tới bệnh lý dạ dày phụ thuộc vào trạng thái có hoạt động hoặc 
không hoạt động "on/off". Một số tác giả khác sử dụng thuật ngữ có mặt hoặc không có mặt "presence/absence". Khi oipA hoạt động sẽ làm tăng nguy cơ loét dạ dày, ung thư dạ dày. Đồng thời nó cũng làm tăng mức độ thâm nhiễm $\mathrm{H}$. pylori trong biểu mô dạ dày, tăng thâm nhiễm bạch cầu đa nhân trung tính ở mức độ nặng [1].

Trong nghiên cứu của chúng tôi trình bày trong bảng 3.4 cho biết tỷ lệ oipA (+) chiếm 10/31 bệnh nhân (32,3\%). Trên thế giới, gen oipA được thực hiện chủ yếu trên bệnh nhân viêm dạ dày mạn, loét dạ dày-tá tràng hoặc loét tá tràng. Các nghiên cứu về oipA ở bệnh nhân UTDD chưa được nhiều. Trong một phân tích tổng hợp (meta-analysis) của Liu ] và cs [4] trình bày bảng 4.1 cho biết về tỷ lệ oipA $(+)$ theo trạng thái "on/off". Kết quả phân tích cho biết tỷ lệ oipA giao động trong khoảng: 66,7-100\%.

Bảng 4.1 Tỷ lệ OipA dương tính ở trạng thái "on/off" [4]

\begin{tabular}{|c|c|}
\hline $\begin{array}{c}\text { Tác giả (năm), } \\
\text { chủng tộc }\end{array}$ & $\begin{array}{c}\text { Tỷ lệ oipA (+) } \\
\text { theo trang thái } \\
\text { "on/off" ơ UTDD }\end{array}$ \\
\hline $\begin{array}{c}\text { Yamaoka Y (2002), } \\
\text { người Mỹ }\end{array}$ & $20 / 30(66,7 \%)$ \\
\hline $\begin{array}{c}\text { Yamaoka Y (2002), } \\
\text { ngươi Colombia }\end{array}$ & $34 / 41(82,9 \%)$ \\
\hline $\begin{array}{c}\text { De Jonge R (2004), } \\
\text { người Đức }\end{array}$ & $8 / 9(88,9 \%)$ \\
\hline $\begin{array}{c}\text { Yamaoka Y (2006), } \\
\text { người Colombia }\end{array}$ & $36 / 40(90,0 \%)$ \\
\hline $\begin{array}{c}\text { Li N (2009), người } \\
\text { Trung Quốc }\end{array}$ & $2 / 2(100 \%)$ \\
\hline $\begin{array}{c}\text { Schmidt (2010), } \\
\text { người Trung Quốc }\end{array}$ & $19 / 22(86,4 \%)$ \\
\hline
\end{tabular}

Cũng với nghiên cứu của Liu J và cs [9], với trạng thái "present/absence" thì tỷ lệ oipA $(+)$ ở bệnh nhân UTDD giao động trong khoảng: 090\% (bảng 4.2).

Bảng 4.2 Tỷ lệ oipA dương tính ở trạng thái "present/absence" [4]

\begin{tabular}{|c|c|}
\hline $\begin{array}{c}\text { Tác giả (năm), } \\
\text { chưng tộc }\end{array}$ & $\begin{array}{c}\text { Tỷ lệ oipA (+) theo } \\
\text { trạng thái "present/ } \\
\text { absence" ở UTDD }\end{array}$ \\
\hline $\begin{array}{c}\text { Zhou M (2009), } \\
\text { người Trung Quốc }\end{array}$ & $18 / 20(90,0 \%)$ \\
\hline $\begin{array}{c}\text { Dabiri H (2009), } \\
\text { người Ba Tư }\end{array}$ & $0 / 4(0 \%)$ \\
\hline $\begin{array}{c}\text { Dabiri H (2009), } \\
\text { người Thô Nhĩ Kỳ }\end{array}$ & $1 / 7(14,3 \%)$ \\
\hline $\begin{array}{c}\text { Xie J (2010), người } \\
\text { Trung Quốc }\end{array}$ & $19 / 27(70,4 \%)$ \\
\hline $\begin{array}{c}\text { Ji CW (2011), người } \\
\text { Trung Quốc }\end{array}$ & $33 / 43(76,7 \%)$ \\
\hline
\end{tabular}

Tuy nhiên, hạn chế của các nghiên cứu này là số lượng bệnh nhân không nhiều, do vậy chưa đánh giá khách quan về tỳ lệ opiA trong UTDD. Cần phải nghiên cứu trên số lượng lớn hơn.

Trong một nghiên cứu gần đây của Braga LLBC và Cs [5] tại miền Bắc-Brazil, đã tiến hành xét nghiệm tỳ lệ oipA ở 95 mẫu $\mathrm{H}$. pylori $(+)$, gồm: 23 bệnh nhân viêm dạ dày mạn, 24 bệnh nhân UTDD, 32 người thế hể thứ nhất của bệnh nhân UTDD và 16 trẻ em. Kết quả nghiên cứu cho biết tỷ lệ oipA $(+)$ chung là: $77 / 81(81,1 \%)$. Kết quả nghiên cứu cho biết tỷ lệ oipA ở trạng thái "on" ở bệnh nhân UTDD và bệnh nhân VDDM tương ứng là: $91,7 \%$ và $60,9 \%$. Mặc dù vậy, tác giả không tìm thấy mối liên quan giữa tình trạng "on" của oipA với UTDD và thế hệ thứ nhất thành viên gia đình của bệnh nhân UTDD. Tuy nhiên, oipA lại có mối liên quan có ý nghĩa với sự hiện diện của cagA và vacA s1 m1.

Tý lệ oipA (+) cũng có sự khác nhau theo các Châu lục khác nhau. Nghiên cứu Sterbenc $A$ và cs [6] cho biết tỷ lệ oipA (+) trên các đối tượng (VDDM, loét dạ dày, loét tá tràng và UTDD) ở Đông Á, Mỹ Latin và châu Âu tương ứng là: $100 \%, 80 \%$ và $60 \%$.

4.3. Vai trò của gen dupA của $H$. pylori ở bệnh nhân UTDD. Gen thúc đẩy loét tá tràng (duodenal ulcer promoting gen: $\operatorname{dupA}$ ) nằm ở vùng plasticity của bộ gen của $\mathrm{H}$. pylori, tương đồng với virB4, một gen mã hóa một protein thành phần của hệ thống tiết týp IV ở vi khuẩn Agrobacterium tumefaciens [7]. Gen dupA bao gồm hai chuỗi liên tục: jhp0917 và jhp0918, như được mô tả trong chủng $J 99$ của H. pylori.

Trong nghiên cứu của chúng tôi trình bày trong bảng 3.4 cho biết tỷ lệ dupA $(+)$ chiếm 16/31 bệnh nhân (51,6\%). Gen dupA được phát hiện vào năm 2005 bởi Lu $H$ và cs [7] khi thực hiện nghiên cứu trên 500 mẫu H.pylori thu thập tại châu Á (Nhật Bản và Hàn Quốc) và ở Colombia. Kết quả nghiên cứu này cho biết dupA có liên quan đến nguy cơ loét hành tá tràng và giảm nguy cơ viêm teo dạ dày và UTDD. Nghiên cứu tiếp theo (2006) được thực hiện tại Trung Quốc bởi Zhang $Z$ và cs trên 360 bệnh nhân, bao gồm: Loét tá tràng $(n=101), \operatorname{VDDM}(n=133)$, UTDD $(n=79)$, loét da dày $(n=47)$. Kết quả nghiên cứu cho biết tỷ lệ dupA (+) ở bệnh nhân: Loét tá tràng, loét dạ dày, UTDD và VDDM tương ứng là: $45,5 \%, 23,4 \%, 24,1 \%$ và $38,3 \%$. Tỷ lệ dupA (+) ở bệnh nhân loét tá tràng tăng cao hơn có ý nghĩa so với loét dạ dày và UTDD $(p<$ $0,05)$. Như vây, dupA tăng cao ở bệnh nhân loét tá tràng, nhưng không tăng ở bệnh nhân UTDD 
và loét da dày.

Tính đến nay (2005-2019) có tổng cộng có 46 nghiên cứu về dupA trên các đối tượng khác nhau. Tập hợp các nghiên cứu này đã khẳng định dupA là một marker gặp nhiều nhất và đặc trưng cho bệnh nhân loét tá tràng, chứ không đặc trưng cho ung thư dạ dày [8]

\section{KẾT LUÂN}

Tỷ lệ cagPAI, oipA, dupA dương tính ở bệnh nhân ung thư dạ dày tương ứng là: 90,3\%, $32,3 \%, 51,6 \%$. Gen cagPAI của $H$. pylori là yếu tố nguy cơ cao gây UTDD tại Việt Nam. Cân nghiên cứu trên số lượng bệnh nhân nhiều hơn.

\section{TÀI LIẸU THAM KHẢO}

1. Yamaoka Y. Mechanisms of disease: Helicobacter pylori virulence factors. Nat Rev Gastroenterol Hepatol. 2010;7(11): 629-641.

2. Maeda S, Yoshida H, Ikenoue $T$, et al. Structure of pathogenicity island in Japanese, Helicobacter pylori, isolates. Gut 1999;44(3): 336-341
3. Ali M, Khan AA, Tiwari SK, et al. Association between cag-pathogenicity island in Helicobacter pylori isolates from peptic ulcer, gastric carcinoma, and non-ulcer dyspepsia subjects with histological changes. World Journal of Gastroenterology 2005; 11(43): 6815-6822

4. Liu J, He $\mathbf{C}$, Chen $\mathbf{M}$, et al. Association of presence/absence and on/off patterns of Helicobacter pylori oipA gene with peptic ulcer disease and gastric cancer risks: A meta-analysis. BMC Infectious Disease 20-13;13: 555-564

5. Braga LLBC, Batista MHR, de Azevedo OGR, et al. OipA "on" status of Helicobacter pylori is associated with gastric cancer in North-Eastern Brazil. BMC Cancer 2019;19(1):48

6. Sterbenc A, Jarc $E$, Polijak $M$, Homan $M$. Helicobacter pylori virulence genes. World Journal of Gastroenterology 2019;25(33): 4870-4884

7. Lu H, Hsu P, Graham DY, Yamaoka Y. Duodenal ulcer promoting gene of Helicobacter pylori. Gastroenterology. 2005;128(4): 833-848.

8. Alam J, Sarkar A, Karmadar BC, et al. Nove virulence factor dupA of Helicobacter pylori as an important risk determinant for disease manifestion: An overview. World Journal of Gastroenterology 2020;26(32): 4739-4752.

\section{ĐẶC ĐIỂM HÌNH ẢNH VÀ MỨC Độ TỔN THƯƠNG PHỔI TRÊN XQUANG NGỰC Ở BÊNHH NHÂN COVID-19}

\section{TÓM TẮT}

Mục tiêu: Mô tả đặc điểm hình ảnh và mức độ tổn thương phổi trên Xquang ngực ở bênh nhân COVID-19. Đối tượng và phương pháp: Nghiên cứu mô tả cắt ngang 370 bênh nhân được chẩn đoán dương tính bằng dịch tỵ hầu điều trị tại bệnh viện Trường Đại học Kỹ thuật $Y$ tế Hải Dương. Kết quả: Tổng cộng 370 BN (157nam(42.4\%) và 213 nữ (57.6\%)): tuổi mắc bênh trung bình 34,$74 ;$. Tổn thương thường gặp nhất là tổn thương kính mờ, đông đăc và đạt đỉnh khoảng ngày $5-9$, tổn thương tràn dịch màng phổi, dày màng phổi và giãn phế quản ít gặp $(<1 \%)$, vị trí hay gặp là vùng ngoại vi, tổn thương cả 2 phổi chiếm đa số. Điểm số nghiêm trọng trên Xquang ngực cao nhất là 12 và đỉnh thường phát hiện ở trong 10 ngày đâu của bệnh.

Tư khóa: COVID-19, Thang điểm trầm trọng trên Xquang ngực, Viêm phổi

\section{SUMMARY}

\section{IMAGING CHARACTERISTICS AND}

*Trường Đai hoc Kỹ thuât Y tế Hải Dương

Chịu trách nhiệm chính: Hoàng Văn Hưng

Email: hungleehmu@gmail.com

Ngày nhận bài: 13.5.2021

Ngày phản biên khoa hoc: 6.7.2021

Ngày duyệt bài: 16.7.2021

\section{Hoàng Văn Hưng*, Nguyễn Văn Thắng*, Phạm Thị Thu Thủy*, Trần Văn Việt*}

\section{SEVERITY OF COVID-19 ON CHEST X-RAY}

Purpose: To describe imaging characteristics and severity of COVID-19 on chest X-ray. Material and method: Descriptive cross-sectional study on 370 patients who tested positive for novel coronavirus by nasopharyngeal swap admitted Hai Duong Medical Technical Univesity Hospital. Result: A total of 370 patients (157 (42.4\%) males and 213 (57.6\%) females): mean age is 37.74; The most common finding on chest $x$-rays was peripheral ground glass opacities, consolidation and peaking around 5-9 days, pleural effusion, pleural thickening and bronchiectasis less common, Most of the patients showed bilateral lung affection. The highest severity score recorded was 12 and peak severity score was reached about less than 10 days admit hospital

Keywords: COVID-19, Chest X-ray severity index, Pneumonia

\section{I. ĐẶT VẤN ĐỀ}

Sars-CoV-2 hiện nay là một đại dịch toàn câu gây ảnh hưởng lớn đến các nước trên thế giới. Ca bệnh khởi phát đâu tiên tại thành phố Vũ Hán - Hồ Bắc - Trung Quốc đến nay đã lây lan ra nhiều quốc gia vừng lãnh thổ trên thế giới và đang là thách thức lớn cho toàn thế giới.

Xquang ngực thường ít có giá trị trong chẩn đoán, phát hiện tổn thương giai đoạn nhẹ so với 